AnUario de Estudios Medievales

43/1, enero-junio de 2013, pp. 83-113

ISSN 0066-5061

doi:10.3989/aem.2013.43.1.04

\title{
ENFERMAR LEJOS DE CASA. LA ATENCIÓN MÉDICA Y VETERINARIA EN LOS HOSTALES DE LA CORONA DE ARAGÓN DURANTE LA BAJA EDAD MEDIA ${ }^{1}$
}

\author{
FALLING ILL FAR AWAY FROM HOME. \\ MEDICAL AND VETERINARY PRACTICE IN THE HOSTELS \\ OF THE CROWN OF ARAGON DURING THE LATE MIDDLE AGES
}

\author{
CARMEl FERRAGUd \\ Universitat de València
}

\begin{abstract}
Resumen: Durante la baja Edad Media la movilidad de las personas fue muy intensa, por razones diversas. Frecuentemente la gente se alojaba en hostales, abundantes en todas las ciudades y también en el mundo rural, donde podían descansar, alimentarse y recibir atención médica para ellos y para sus caballerías. Dichos hostales fueron ámbitos propicios para la intervención de barberos y cirujanos, pues en ellos se producían muchas trifulcas con heridos.
\end{abstract}

Palabras clave: barberos-cirujanos; albeitería; hostelería; medicina doméstica; burdel.

\begin{abstract}
During the late Middle Ages the mobility of people was intense, for various reasons. Frequently, people stayed in hostels, which were abundant in all cities and in the countryside and where they could rest, eat and receive medical care for themselves and their horses. These hostels were favourable environments to the intervention of barbers and surgeons, because many fights resulting in injuries took place there.
\end{abstract}

Keywords: barber-surgeons; marshallship; hostelry; domestic medicine; brothel.

\section{SUMARIO}

1. Introducción.-2. Algunas pinceladas sobre la hostelería medieval.- 3. Hostaleros y hostaleras.- 4. Cirujanos y barberos en el hostal.- 5. El hostal y la atención a los equinos enfermos.- 6. Enfermo en casa ajena.- 7. Conclusiones.- 8. Bibliografía citada.

${ }^{1}$ Abreviaturas utilizadas: $\mathrm{ACA}=$ Archivo de la Corona de Aragón; $\mathrm{ACB}=\mathrm{Arxiu}$ Capitular de la Seu de Barcelona; AHPB=Arxiu Històric de Protocols de Barcelona; ARV=Archivo del Reino de Valencia; $\mathrm{C}=$ Cancillería Real; $\mathrm{RP}=$ Real Patrimonio; $\mathrm{MR}=$ Mestre Racional; $\mathrm{JCv}=\mathrm{Justicia}$ Civil; JCr=Justicia Criminal. Quiero agradecer a Teresa Huguet-Termes, Ferran Illana, Carles Vela y a los evaluadores sus amables y acertados comentarios. Este trabajo forma parte del proyecto de investigación financiado por el Ministerio de Ciencia e Innovación "Corpus digital de la ciencia medieval en la Corona de Aragón en su contexto latino y románico: obras vernáculas, Arnau de Vilanova y Vicent Ferrer (CIVERLAT)", FFI2011-29117-C02. 


\section{INTRODUCCIÓN}

El hombre y la mujer medievales vivieron acechados y preocupados permanentemente por la presencia de la enfermedad. Las circunstancias particulares en que se desarrollaban sus vidas durante la baja Edad Media hicieron que las tasas de enfermedad fueran muy altas. Prevenirla o hacerle frente con los más variados recursos de los que se pudiera disponer estaba siempre entre sus preocupaciones y prioridades ${ }^{2}$. Desde el uso de los recursos propios y de los conocimientos familiares transmitidos de generación en generación, casi siempre de madres a hijas, al empleo de ensalmos y oraciones, curanderos, adivinos y sanadores del más diverso pelaje, desde empíricos "especialistas" en determinadas dolencias a médicos con formación universitaria, cualquier recurso de forma aislada o bien la combinación de varios de ellos eran bienvenidos, aunque a veces éstos no fueran del gusto de las autoridades eclesiásticas y se encontraran permanentemente bajo sospecha ${ }^{3}$. Efectivamente, como ha quedado demostrado, los hombres y las mujeres de tiempos pretéritos buscaron la complementariedad de los ámbitos familiar, comunitario (vecindario, amistades) e institucional (hospitales, asilos, cofradías) para curarse de sus enfermedades. Aunque la prevalencia en el uso de uno u otro según las épocas parece clara, nunca uno cerró el paso al otro en esta "economía del cuidado", en palabras de Horden, sino que lo habitual fue la asistencia flexible y diversa ${ }^{4}$.

En este contexto, el papel de las mujeres en la atención a los enfermos que vivían bajo su techo resulta innegable. La sabiduría tradicional que acarreaba la experiencia acumulada las convirtió en las primeras asistentes médicas del conjunto de la población, y parece que esto ocurrió sin diferencia de clase. La fama de algunas, sin embargo, trascendió al vecindario, la comarca o incluso más lejos y se convirtieron en sanadoras de gran popula$\operatorname{ridad}^{5}$. Pero a menudo los conocimientos de las mujeres en el hogar no eran suficientes y se buscaron médicos profesionales o se optó por otros sanadores fuera del marco de la medicina oficial enseñada en la universidad y basada en el llamado galenismo médico ${ }^{6}$.

\footnotetext{
${ }^{2}$ K. Park, Medicine and society, pp. 60-74.

${ }^{3}$ Un predicador como Vicente Ferrer denunció constantemente en sus sermones el recurso habitual a ensalmadores, adivinos y otro tipo de sanadores sospechosos de invocar al diablo e imponer oraciones con fines curativos ajenas a la ortodoxia cristiana. R. Narbona, Tras los rastros de la cultura popular, pp. 91-110; J.A. Ysern i Lagarda, Sant Vicent Ferrer: Predicació i societat, pp. 73-102.

${ }^{4}$ P. Horden, Household care, p. 29.

${ }^{5}$ M. Cabré, Women or healers?, pp. 31-36; C. Ferragud, La atención médica doméstica, pp. 137-140 y 144-149.

${ }^{6}$ N. Siraisi, Medieval \& Early Renaissance Medicine, pp. 17-47.
} 
Esta omnipresente preocupación por la enfermedad ha quedado puesta de manifiesto en diversas fuentes escritas, como textos religiosos y literarios. Pero resultan especialmente conmovedoras y esclarecedoras, con respecto a este miedo a la enfermedad, las imágenes vertidas por la correspondencia privada emitida por la clase nobiliaria y burguesa, saturada de referencias a la salud y la enfermedad, de consultas a familiares y amigos sobre su estado ${ }^{7}$. Y esta preocupación ha quedado así reflejada precisamente por la distancia física entre los interlocutores, familiares o amigos, al no poder conocer directamente el problema y contribuir de alguna forma a solucionarlo. ¿Cómo podrían estos individuos tan estimados ser consolados y ayudados en momentos tan difíciles para una persona como son la enfermedad y el dolor experimentados muy lejos del hogar?

Efectivamente, el estilo de vida, el oficio, la búsqueda de una vida mejor y las diversas opciones personales que pudieran llevar a los hombres y a las mujeres a desplazarse por los caminos o a embarcarse en alguna nave hacia tierras lejanas, hicieron de la Europa bajomedieval un lugar donde los movimientos de población fueron constantes, sobre todo ante determinadas coyunturas. Por los polvorientos y a menudo casi impracticables caminos se desplazaban numerosos individuos, movidos por circunstancias muy diversas $^{8}$. Pero esta era una aventura que podía costar cara, pues la inseguridad producto del estado de estos caminos, la presencia de delincuentes o las inclemencias meteorológicas podían conducir a la desgracia. El riesgo de enfermar era evidente. Por eso no ha de extrañar que desde el siglo XIII se escribieran "regímenes de sanidad" especialmente pensados para la higiene durante los viajes ${ }^{9}$. En estos textos se tenía en cuenta la preparación necesaria antes de emprender el camino, el aprovisionamiento de comida y bebida, la protección ante las inclemencias meteorológicas, así como la fatiga y el descanso.

Pero la realidad de la enfermedad no solo afectaba a los humanos. Los equinos empleados con mayor frecuencia en estos desplazamientos - mulas, rocines, caballos- acababan agotados, torturados por los trayectos y las cargas que trajinaban en sus lomos. Únicamente la llegada al lugar de hospedaje permitía un descanso y el reposo del cuerpo maltrecho. En este sentido, el hostal se convirtió en la opción más habitual y en uno de los lugares de cura

\footnotetext{
${ }^{7}$ La correspondencia conservada en la Cancillería Real pone de manifiesto la angustia permanente y la preocupación constante por el tema. M.R. McVaugh, Medicine before the plague, pp. 14-24; J.M. Roca, La medicina catalana, pp. 82-106. Con respecto a la correspondencia entre burgueses en Cataluña, véase Epistolari del segle XV, pp. 38-118.

${ }^{8}$ Pueden verse diversas causas, particularidades y tipos de desplazamientos en la Edad Media en los siguientes volúmenes: Viajes y viajeros en la España Medieval; S. Gensini (ed.), Viaggiare nel Medioevo; R. Beltrán (ed.), Maravillas, peregrinaciones y utopías.

${ }_{9}^{9}$ L. García Ballester et al., Regimen sanitatis ad regem Aragonum, pp. 384-394.
} 
para el viajero medieval y sus animales. ¿Qué ocurría cuando alguien era sorprendido por la enfermedad a leguas de distancia de su lugar de origen? ¿Qué recursos podían utilizarse entonces, privados de la seguridad del hogar y de los cuidados femeninos maternos o conyugales, o de los sanadores conocidos a los que se recurría habitualmente?

A menudo, los estudios que se ocupan de la historia social de la medicina no se detienen demasiado en los escenarios donde se realizaba el acto de curar y atender enfermos, si exceptuamos las instituciones hospitalarias, por otro lado lugares no concebidos específicamente con esta finalidad ${ }^{10}$, o los obradores de barbería o de albeitería, lugares pensados precisamente para llevar a cabo la mayor parte de las acciones terapéuticas en humanos y animales respectivamente ${ }^{11}$. Sin duda, buena parte de esta desatención historiográfica está relacionada con las fuentes para su estudio. Para el caso de la Corona de Aragón, las fuentes archivísticas son extraordinariamente abundantes y fecundas, pero, sin embargo, no resultan tan clarificadoras respecto al tema que aquí se plantea. Desde que empecé una labor de vaciado sistemático de archivos de toda índole -reales, nobiliarios, municipales y eclesiásticos- con motivo de la preparación de mi tesis doctoral (2002), material al que se debe sumar el ya exhumado por Luis García Ballester y sus discípulos y por Michael McVaugh, he registrado miles de fichas para temas relacionados con la salud, la enfermedad y la práctica médica, y he localizado más de seiscientos practicantes de la medicina ${ }^{12}$. El resultado de esta búsqueda y ordenación sistemática ha permitido acercarse de alguna forma a estos espacios donde los viajeros que llegaban a una ciudad podían buscar atención para ellos o sus bestias: los hostales. En este sentido, podemos afirmar que los estudios que se han dedicado al tema no recogen en ningún momento datos sobre la asistencia a los enfermos, con lo que el presente trabajo cobra mayor relevancia ${ }^{13}$. Pero la hospitalidad medieval en las ciudades iba más allá del ámbito profesional de los hostales. Por esta razón, en la parte final trataré también de la hospitalidad de carácter privado que se dio en el marco doméstico.

\footnotetext{
${ }^{10}$ Sobre los hospitales de la Corona de Aragón y la pluralidad de individuos atendidos, más allá de la enfermedad, véase J. W. Brodman, Charity \& welfare, pp. 1-7. Para el caso valenciano A. Rubio Vela, Pobreza, enfermedad y asistencia hospitalaria, pp. 44-49.

${ }^{11}$ Para el caso valenciano C. Ferragud, Els barbers, pp. 31-57. Sobre los talleres de los menescals o albéitares, véase C. Ferragud, La cura dels animals, pp. 82-90.

${ }^{12}$ Puede verse una muestra de la variedad de fuentes exhumadas y de practicantes registrados, en C. Ferragud, Medicina i promoció social, p. 17, 36 y el índice onomástico.

${ }^{13} \mathrm{El}$ trabajo más completo sobre el tema es el de H. C. Peyer, Viaggiare nel medioevo. Más recientemente puede verse una síntesis en M. Berengo, L'Europa delle città, pp. 512-519.
} 


\section{AlgunAS PINCELADAS SOBRE LA HOSTELERÍA MEDIEVAL}

Hostales y tabernas formaban parte del paisaje cotidiano de pueblos y ciudades de la Edad Media. Se encontraban diseminados por toda la geografía urbana, sobre todo cerca de sus puertas, en los burdeles, pero también muchos se habían emplazado en diversos puntos neurálgicos de los caminos. Los individuos de aquella sociedad en permanente movilidad necesitaban estos enclaves donde permanecer temporalmente bajo techo y bien alimentados.

Ahora bien, definir qué es un hostal durante la Edad Media y cuáles son sus funciones resulta bastante complejo, ya que las actividades que se llevaban a cabo en estos establecimientos iban más allá del alojamiento y suministro de vituallas a los viajeros. Efectivamente, los hostaleros y hostaleras se habían pertrechado con los recursos que eran necesarios para atender a sus huéspedes, tales como las camas, los alimentos y las bebidas. Pero resulta evidente que, como ocurriera con la taberna -con la que a menudo se puede confundir el hostal-, los habitantes de la ciudad se mezclaban con aquellos individuos que estaban de paso y protagonizaban conjuntamente veladas donde el juego con apuestas y el consumo abusivo de vino eran habituales. Incluso en algunos casos era posible satisfacer los ardores de la carne con las prostitutas que algunos propietarios de hostal controlaban.

Efectivamente, la historia de la prostitución a menudo confluye con la historia del hostal. Así, los hostaleros del burdel de Valencia mantenían prostitutas y estaban obligados a darles comida, bebida y asistencia médica cuando la necesitaban ${ }^{14}$. El aspecto externo de éstas y su salud eran muy importantes y debían estar bien cuidadas para no ir en contra de los intereses económicos de sus mantenedores. Éstas invertían mucho en su propio adorno corporal, e incluso los hostaleros les prestaban dinero con este fin. También había hostaleros que mantenían mujeres como si fueran inquilinas o criadas pero para prostituirlas ilegalmente. Un repaso a la historia de los hostales, los burdeles y la prostitución en general en villas y ciudades de toda Europa nos lleva a la conclusión que el fenómeno era muy común ${ }^{15}$. Por eso, las reglamentaciones municipales valencianas insistían en la prohibición de mantener prostitutas en los hostales que no fueran al mismo tiempo burdeles. Tal sería el caso de Alzira, Castellón de la Plana o Llucena ${ }^{16}$.

${ }^{14}$ V. Graullera, Los hostaleros del burdel de Valencia, pp. 201-216; M. Carboneres, Picaronas y alcahuetas, pp. 80-85 (12-III-1495). El caso de Florencia pone de manifiesto la ubicuidad de la prostitución más allá de los burdeles, en tabernas, hostales, baños y locales alquilados con este fin. M.S. Mazzi, Prostitute e lenoni, pp.249-292.

${ }^{15} \mathrm{~J}$. Rossiaud, La prostitución en el Medievo, p. 75.

${ }^{16}$ Establiments municipals del Maestrat, p. 106. Libre de diversos statuts e ordenacions, p. 137. En Alzira solo se les podía dar alojamiento por una noche. 
La imagen del hostal vertida por la literatura de la época evoca escenas donde el sexo y las actitudes reprobables por parte de la moral católica encuentran un fácil desarrollo. Y así lo podemos entrever en los sermones del predicador dominico Vicente Ferrer. Sus menciones a los hostales no eran sino para prevenir al peregrino -y especialmente a las peregrinas- de los peligros que allí podían encontrar, y más si viajaban en gran compañía. Así, el dominico aconsejaba el viaje espiritual en lugar de los largos desplazamientos que obligarían a hospedarse en hostales y tabernas, donde el hacinamiento incitaba al pecado y donde la pretendida virtud se convertía en lujuria y transformaba las mujeres en rameras ${ }^{17}$. Mantener prostitutas en estos establecimientos era una forma inadmisible de fortalecer la lujuria de todo tipo de individuos, ya que en los hostales y tabernas podían alojarse personas de toda condición, laicos y religiosos, y también mudéjares y judíos. Era necesario que las autoridades recluyeran las prostitutas en las áreas destinadas al burdel, con sus propios hostaleros. Para Vicente Ferrer esta lujuria podía corromper el cuerpo de forma semejante a la lepra. Y éste era un problema que encontraba en todos los lugares por donde pasaba predicando ${ }^{18}$.

Vicente Graullera nos ha proporcionado también abundantes imágenes de las particularidades de los hostales valencianos como espacios donde la trasgresión y las pasiones de la carne fluyen con frecuencia. Aunque procedentes del siglo XVI, diversas denuncias ante la Gobernación del reino muestran que en estos espacios sus inquilinos se veían obligados frecuentemente a compartir la misma cama, aunque no se conocieran antes de llegar al establecimiento. Los intereses sexuales de unos chocaban con los de otros, que, ofendidos o agredidos, cuando no sodomizados contra su voluntad, acudían a la justicia ${ }^{19}$.

Otra imagen perniciosa del hostal, que también vale tanto para la gran ciudad como para las pequeñas villas rurales, es la de lugar donde se fomentaba la embriaguez. Este sería el caso de Sueca, un pequeño pueblo de campesinos de la Ribera del Xúquer. El proceso que en 1381 enfrentó este lugar -que formaba parte del señorío de la Orden de Montesa- con la ciudad de Valencia, obligó a tomar declaración a un gran número de vecinos. Veinticuatro de ellos fueron recusados por el vicio de embriaguez, hecho que les hacía indignos para que su testimonio fuera aceptado ante un tribunal. La embriaguez de la que se acusaba a aquellos suecanos siempre estaba asociada a la taberna y al hostal ${ }^{20}$.

\footnotetext{
${ }^{17}$ V. Ferrer, Sermons, vol. III, pp. 79 y 127; vol. V, p. 57.

${ }^{18}$ Sermonario de San Vicente Ferrer, p. 751.

${ }^{19}$ V. Graullera, Delito de sodomía, pp. 229- 233 y 237-238.

${ }^{20}$ A. Rubio Vela, El procés de Sueca, pp. 63-66. En general así ocurrió con los hostales de la Europa occidental, H. C. Peyer, Viaggiare nel medioevo, p. 261.
} 
El hostal también se convirtió en marco ideal para cerrar negocios. Hay que tener en cuenta que era allí donde solían residir los mercaderes foráneos, donde éstos se entrevistaban con sus clientes y donde cerraban sus transacciones. En ocasiones, el hostal actuaba como depósito en donde dejar temporalmente las mercancías. Así se deduce de los fueros de Valencia, que obligaban a los hostaleros a restituir estos bienes a sus propietarios ${ }^{21}$. Es indudable que el regente del hostal se encontraba en una posición adecuada para mediar en estos negocios, circunstancia que las autoridades combatieron prohibiendo a los hostaleros ejercer de comerciantes e intermediarios. Aunque las autoridades pretendían separar las actividades comerciales de las hosteleras, dicha separación solo se consiguió en la medida en que los sistemas de poder pudieron ejercer su control y coerción ${ }^{22}$.

En diversos lugares del reino de Valencia, como fue el caso de Llucena, Catí y Morella, en el norte, y de Alzira, cerca de la capital, se prohibió a los hostaleros revender al detalle las mercancías que pudieran entrar en el hostal (vino, pan o aceite) o, en su lugar, se establecieron los límites para los precios que éstos podían cobrar en sus establecimientos. Por ejemplo, era habitual y estaba permitido que en un hostal hubiera cebada, pero solo para la alimentación de los equinos que lo frecuentaban. Además, los hostaleros debían venderla a un precio fijado por las autoridades. En Morella, Valencia y Alzira se insistió en que hostaleros y corredores no interfirieran mutuamente en sus ocupaciones y que, igual como se prohibía a un corredor alojar en su casa a un mercader, el hostalero no debía hacer de intermediario en negocios por su cuenta $^{23}$. Asimismo, debía permitir la entrada a su establecimiento a los corredores y considerar el hostal como un espacio público, prohibiéndoseles exigir ningún tipo de compensación por los tratos que el corredor pudiera realizar en el hostal. En este caso, las frágiles multas de cinco sueldos se elevaban a sesenta, síntoma de que las autoridades querían ser especialmente coercitivas, seguramente por los problemas que la confrontación entre estos dos oficios hubiese suscitado, tal como se explicita en el caso de la ciudad de Valencia, donde este detalle se reglamentó con gran minuciosidad ${ }^{24}$.

${ }^{21}$ G. Colón, A. Garcia (eds.), Furs de València, vol. 2, p 243: "Nauxers, taverners, ostalers, qualque cosa o mercaderia de grat o de volentat o en altra manera, reebran d'alcú, salvament la restituesquen" (llibre 2, rúbrica 16).

${ }^{22}$ H. C. Peyer, Viaggiare nel medioevo, pp. 237-238; M. Gual Camarena, El hospedaje hispano-medieval, p. 452. En 1364, Pedro IV prohibió que los hostaleros valencianos se metieran en los asuntos de los corredores. Ocho años después se prohibió en Barcelona. Sin embargo, parece evidente que durante bastante tiempo se siguieron confundiendo ambas funciones.

${ }^{23}$ Libre de diversos statuts e ordenacions, pp. 141, 157 y 197; Establiments municipals del Maestrat, pp. 106, 301, 413.

${ }^{24}$ Ibidem, p. 445. Para el caso de la ciudad de Valencia, véase Llibre d'establiments $i$ ordenacions de la ciutat de València, pp. 85 i 99. 


\section{Hostaleros y hostaleras}

Con la imagen perniciosa del hostal que se desarrolló en la literatura de la época, parece lógico que sus regentes tuvieran una consideración bastante negativa entre sus contemporáneos ${ }^{25}$. Pero como intentaré mostrar, estas objeciones no pasaron de ser un producto más de los argumentos moralizantes de los predicadores, que tan a menudo luchaban contra costumbres bien arraigadas en la sociedad. Lógicamente, el hostal y la taberna, como lugares donde el juego, el vino, el baile y la prostitución eran inquilinos asiduos, debían estar en el punto de mira de los inflamados sermones bajomedievales. Sin embargo, el carácter marginal solo debió afectar a una parte del colectivo. Los hostaleros del burdel, de hecho, no ocultaban esta condición y, al contrario, no estaban mal considerados ${ }^{26}$. También otro tipo de noticias nos alertan sobre la categoría social de algunos hostaleros. Así, por ejemplo, cuando el hostalero de la ciudad de Valencia Domingo Robins hizo su testamento en 1382 se permitió nombrar como albaceas al físico ciudadano de Valencia Vicent Serra y al presbítero Ramon Armengol ${ }^{27}$. Las noticias documentales de que disponemos de este médico valenciano nos permiten deducir que tenía un cierto prestigio y una posición social solvente. Era hijo del físico de Xàtiva Pere Serra y tenía una hermana llamada Isabel, afincada en la misma ciudad, y su hermano Pere era licenciado en derecho y canónigo de la catedral de Valencia. De su holgada posición económica nos hablan sus préstamos monetarios, el hecho de ser propietario de una heredad en Valencia y de inmuebles en Xàtiva, así como su participación en la venta de esclavos ${ }^{28}$. Sería sorprendente que un médico de esta categoría hubiese aceptado ejercer de albacea testamentario de Domingo Robins, si este hubiese sido un individuo que se pudiera catalogar como despreciable por la sociedad. Como también pueden sorprender los negocios que pueden emprender algunos hostaleros. Este es el caso de Jaume Alfonso, quien vendió a un mercader llamado Mateo Ramacci, por un precio de 200 florines, la

\footnotetext{
${ }^{25}$ J. Le Goff, Oficios lícitos e ilícitos, p. 90. Diversas piezas literarias francesas cuelgan a menudo una mala reputación a los hostaleros, personas groseras que abusan de sus clientes, les engañan y pueden llegar a asesinarles con tal de conseguir sus bienes. Pero, de la misma forma, otras obras les catalogan de personas dignas de confianza. J.L. Picherit, L'hôtellerie, les hôteliers et hôtelières, pp. 312-318. En Sueca dos de los testigos rechazados en el proceso anteriormente citado eran taberneros, considerados personas de baja condición. A. Rubio Vela, El procés de Sueca, p. 66.

${ }^{26}$ V. Graullera, Los hostaleros, pp. 204-205.

${ }^{27}$ ACA, C, reg. 940, ff. 35v-37 (1382).

${ }^{28}$ Anualmente recibía una pensión de 500 sueldos por un violario que satisfacían diversos individuos. ARV, Protocolos, $\mathrm{n}^{\circ}$ 2822, s.f. (10-10-1385). Diversos documentos sobre Vicent Serra son recogidos en J.L. Fresquet et al, Archivo Rodrigo Pertegás.
} 
mitad de una nave castellana que tenía anclada en el puerto de Ibiza. Posteriormente nombraría al mismo hombre patrón de la nave ${ }^{29}$.

Ahora bien, debemos considerar que en el mundo de la hostelería existían grandes diferencias internas. Algunos eran humildes locales cómo el del valenciano Joan Llorenç, con apenas dos habitaciones con un par de camas, que pocos huéspedes podrían albergar ${ }^{30}$. No dejan de parecer sorprendentes, en cambio, los datos que rebela el inventario de otro hostal en la misma ciudad, el de Domingo Conill, también de modestas dimensiones pero pertrechado de objetos de gran interés ${ }^{31}$. De éste se hizo un listado de bienes para hacer frente a la acusación de hurto que habían formulado en contra suya algunos vizcaínos que se habían alojado en su taberna-hostal. Se trataba de un pequeño establecimiento en el que apenas se localizan cinco camas. Nada parece fuera de lugar en un sitio como éste, excepto algunos libros y objetos científicos. Y es que, por lo que parece, la escritura formaba parte de la cultura de los propietarios del hostal. Efectivamente, en el inventario son recogidos hasta un total de ocho libros de cuentas, un cuaderno, una carta escrita en papel, cinco cartas enrolladas de pergamino, una carta de noliejament, más un testamento y una carta de venta. También, para llevar buena cuenta del dinero acumulado, existía una báscula de pesar florines: Ítem, un pesal de florins ab dos pedres de toch e VII pesals, entre grans e xichs.

En aquel tiempo, la contabilidad formaba parte de la cultura de los mercaderes y artesanos de la más diversa índole. Desde un humilde barbero a las sociedades mercantiles más avanzadas había una gran distancia, pero todos ellos estaban convencidos del valor y la necesidad de contar con instrumentos escritos, que eran indispensables para llevar adelante sus negocios ${ }^{32}$. Hasta aquí todo parece dentro de lo habitual, sin embargo llama la atención en este inventario la presencia de un librito escrito en latín, del que no se da más detalle, un pequeño catón y dos volúmenes que tienen especial interés para nuestro estudio: dos libros dedicados al cuidado de los animales (Ítem, un libre vell qui comença: "Pelagius propi mular"; Ítem, un libre de paper de medecines de bèsties). Aunque su identificación resulta absolutamente im-

\footnotetext{
${ }^{29}$ ARV, Protocolos, $n^{\circ} 2415$, f. 421 (20-10-1414).

${ }^{30} \mathrm{ARV}, \mathrm{JCv}, \mathrm{n}^{\mathrm{o}} 394$, m. 3, f. 12 (3-4-1378).

${ }^{31}$ Este hostalero poseía una masía llamada el Poalet, en el término de la ciudad de Valencia. En este lugar se inventariaron todas las herramientas necesarias para el trabajo de la tierra, una explotación agrícola que muy posiblemente servía para que el hostal pudiera suministrarse de al menos algunas de las provisiones necesarias para los clientes.

${ }^{32}$ Sobre las causas, las formas y el desarrollo de la educación en la Valencia medieval, véase J.M. Cruselles, Escuela y sociedad, pp. 199-205. Sobre la importancia de las contabilidades para los boticarios, véase C. Vela, L'obrador d'un apotecari, pp. 32-44. Sobre los barberos, véase C. Ferragud, Medicina i promoció social, pp. 258-264.
} 
posible, no hay duda de que la conexión con la atención de los equinos que era dispensada en los hostales, como veremos más adelante, nos hace pensar en la posibilidad de que estuvieran allí para uso de los albéitares, o incluso de los mismos hostaleros, pues uno de los libros parece una colección de recetas con las que pudieran atender ocasionalmente los animales enfermos. De hecho, los albéitares poseían en sus bibliotecas los manuales básicos que les servían en sus actividades cotidianas. Eran un instrumento más de progreso social, vinculado al conocimiento técnico de las materias, típico también de la medicina y de la cirugía humanas, que permitía ir más allá del herraje de los caballos $^{33}$.

Sin embargo, no terminan aquí las sorpresas de este inventario. Otros animales eran también del gusto de este hostalero: los halcones. Efectivamente, en el hostal se documentan dos guantes con cuatro cascabeles y dos gorros para halcón (Ítem, dos guants ab quatre cascavells e dos capells de falquó). Se trata de los elementos necesarios para controlar estos animales, junto con las correas, que no son citadas. Es la manifestación de que una actividad presuntamente elitista como era la caza con aves, al principio solo apta para una élite, se había puesto al alcance del propietario de un hostal, como también se difundió entre otros muchos individuos que la pusieron en práctica ${ }^{34}$. Pero si este hallazgo resulta sorprendente, no menos lo es la inclusión de instrumentos propios de la navegación, como son las cartas de navegar y los compases (Îtem, una carta de navegar ab un libre de compàs xich e un compaset petit). Tal vez no estemos más que frente a objetos tomados como garantía ante un préstamo, incluso pudiera ser que fuesen robados, si atendemos a la acusación de los vizcaínos. En cualquier caso, no cabe duda de su importancia y su valor, al menos para quien lo depositó. En definitiva, este inventario nos viene a indicar que los hostaleros eran personajes que podían contar con una cierta cultura con una base doctrinal que incluía intereses diversos, también de carácter científico, independientemente del uso que pudieran hacer de ellos para su negocio. Pero no es este el único caso sorprendente.

El 12 de enero de 1380, Pere Sasala, de la tesorería del rey Pedro el Ceremonioso, explicó al justicia criminal de Valencia que hacía tres años el monarca le había enviado de viaje a Portugal para entregar un mensaje al rey portugués ${ }^{35}$. A su paso por Valencia se detuvo en el hostal de la Plaça de la

\footnotetext{
${ }^{33}$ Sobre los inventarios de albéitares y la posesión de libros de su arte, véase C. Ferragud, La cura dels animals, pp. 92-93; idem, La atención médica de los animales, p. 37.

${ }^{34}$ Un completo estudio sobre el tema, incluyendo la difusión de la cetrería entre cualquier colectivo social de la Edad Media, en R.S. Oggins, The Kings and their hawks, p. 114.

${ }^{35} \mathrm{ARV}, \mathrm{JCr}, \mathrm{n}^{\circ} 45$, s.f. (12-1-1380).
} 
Figuera, regentado por un tal García Sánchez. Consigo llevaba una aljaba o estuche de cuero cerrado por un candado. En este estuche llevaba guardados unos libros y una carta de deuda:

una bíblia en romanç, un llibre d'estrologia e altre libre de medicina e cirurgia de maestre Arnau de Villanova, e altre de Salamó, apellat Rasuell, e altre llibre de offici de la monederia e altre libre que tractava de alquímia, e una carta de deute per CCCC florins.

Solamente los libros estimó que podían valer 1.000 florines de oro. Sasala dejó el estuche encomendado al hostalero, pero éste lo abrió sin permiso. El hostalero se defendió diciendo que su cliente havia fogit sens comiat e sens paga. Si fue el valor económico o bien el valor intelectual, o ambas cosas, lo que atrajo al hostalero no lo sabemos, pero el botín habría hecho las delicias de cualquier interesado en la ciencia ${ }^{36}$. La circunstancia también nos habla de la importancia de estos textos, transportados como equipaje inseparable y bien custodiado en largos trayectos ${ }^{37}$.

Por otro lado, en estos hostales cobró gran importancia la presencia femenina. Así, la literatura laica y religiosa suele evocar la figura de la hostalera o hosta. Como se ha indicado en general para otros ámbitos europeos, esta mujer ejercía un papel notable en el hostal. Suelen retratarse con un carácter fuerte y ejerciendo una gran influencia sobre el marido $^{38}$. Seguramente esto era producto de la necesidad de tratar con numerosos inquilinos a los que se debía hacer frente, pues la mayoría debían ser desconocidos y gente de paso. Además, las labores que se ejercían en el hostal y la taberna no eran sino una multiplicación de las tareas domésticas que realizaba una mujer en cualquier casa: gestionar, alimentar, limpiar y curar. También desarrollaban otros oficios complementarios, como el hilado, para completar los ingresos domésticos, labor que era practicada habitualmente por las mujeres. Así, por ejemplo, en el Espill, Jaume Roig hace una mención a una hostalera, propietaria de un hostal en la entrada de la ciudad, que hilaba lino. En este caso nos dibuja un

${ }^{36}$ Que algunos hostaleros contaban con una formación particular lo demuestra el hecho que el hostalero Pere Giner actuó hasta ocho ocasiones como intérprete del árabe (torsimany) cuando esclavos sarracenos capturados eran llevados para su interrogatorio ante el baile general. F.J. Marzal, La esclavitud en Valencia, p. 906.

${ }^{37}$ No podemos precisar con qué finalidad -simple lectura o uso práctico- llevaba consigo Pere Sasala estos libros.

${ }^{38}$ J.L. Picherit, L'hôtellerie, les hôteliers et hôtelières, pp. 318-324. En el hostal de l'Àngel de la ciudad de Valencia era la hosta quien recibía a los clientes. Su habitación estaba en la parte derecha de la entrada del hostal. ARV, Governació, Litium, no 2313, mano 23, ff. 21-44 (20-9-1464). 
personaje poco fiable, que acabará robándole al protagonista una bolsa que contenía una letra de cambio ${ }^{39}$.

Una de las cuestiones que más llaman la atención es que estas mujeres sean titulares de estos establecimientos en algunas tallas realizadas con objetivos fiscales. En el caso de Valencia, podemos citar en la parroquia de Sant Joan del Mercat los hostales de Pasquala, Beneita y Caterina ${ }^{40}$. También en algunas regulaciones municipales se indica que van dirigidas tanto a hostalers como a hostaleres, en clara alusión a la presencia femenina y a su protagonismo. Curiosamente, en las fuentes literarias valencianas también se recoge con insistencia la figura de la hostalera, por delante de su homónimo masculino. Así, en una de las escasas referencias que el dominico Vicente Ferrer hizo de los hostales en sus sermones, aparece la figura de la hostalera, a la cual se dirige en una de sus visitas a Valencia ${ }^{41}$. También en el Espill de Jaume Roig aparecen citadas dos hostaleras. Ahora bien, en estos casos se deja ver la mala fama de que gozaron en buena medida estos establecimientos y sus regentes, especialmente las mujeres, aunque en la novela de Roig debemos también tener en cuenta el marcado carácter misógino. Ya hemos hablado anteriormente a propósito del protagonista del Espill y su mala experiencia con la hostelera que le robó su bolsa. En otro episodio, en Santo Domingo de la Calzada, una hostalera será la culpable de que se condene a muerte a un peregrino, después de una falsa acusación de robo. Este peregrino sobrevivirá gracias a un conocido milagro del apóstol Santiago. Aunque este es un episodio repetido en numerosas fuentes, producto de la tradición cristiana, no deja de ilustrar la connotación negativa de la hostalera. En este mismo sentido hay que entender el uso de la palabra hosta en el Espill como metáfora de la maldad de las mujeres ${ }^{42}$.

Seguramente la ocupación de hostalera debió de ser una de las que mayor libertad y autoridad permitió a una mujer en la Edad Media ${ }^{43}$. Se tiene

${ }^{39}$ J. Roig, Espill, p. 116.

${ }^{40}$ A. Rubio Vela, M. Rodrigo, Antroponímia valenciana del segle XIV, pp. 64, 65 y 66. Un tanto ocurría también en la ciudad de Mallorca, donde se registran diversas mujeres catalogadas de taberneras o hostaleras: "la dona Sabastiana, tavernera", "la dona Iohane", "Margarita, ostalera del bordell", "la viuda Basseta, tavernera", "Lapandera, hostalera". M. Barceló, La talla de la ciutat de Mallorca, pp. 26, 31, 43, 67, 74, 80, 126.

${ }^{41}$ V. Ferrer, Sermons, vol. III, p. 79.

${ }^{42}$ J. Roig, Espill, pp. 178 y 348. Y sin embargo algunas fuentes francesas no dejan de catalogarla como mujer que se distingue por su bondad y su compasión, que acoge e incluso atiende enfermos. J.L. Picherit, L'hôtellerie, les hôteliers et hôtelières, p. 319.

${ }^{43}$ Aunque, sorprendentemente, en alguna obra monográfica sobre el trabajo de la mujer en la Edad Media no he podido localizar ningún caso de dedicación de las mujeres a la hostelería dentro de la gran pluralidad de ocupaciones ejercidas por éstas, e incluso como herederas y titulares de los negocios que habían sido propiedad de sus maridos después de enviudar. Á. Muñoz, C. Segura (eds.), El trabajo de las mujeres. 
la sensación de que estas mujeres deben hacer frente a obligaciones que exigen un carácter fuerte y una decisión y una autoridad contundentes. Por un lado, las numerosas personas que se dejan caer por los hostales, no siempre con buenas intenciones, exigen esta contundencia y capacidad de actuación. Pero, por otro lado, debe tenerse en cuenta que la mayor parte de las atenciones terapéuticas se llevaban a cabo en el hogar y por mujeres y, en este sentido, la hostalera cobra un sentido especial desde la perspectiva de la historia de la medicina, al convertirse, también junto a sus maridos, en favorecedores de la salud, ya sea directamente o a través del contacto con practicantes de la medicina y la albeitería medievales.

Pero un local que podía tener un buen movimiento de personas y animales a los que alimentar y dar un cobijo, debía dar mucho trabajo. En este sentido, no resulta nada extraño que los hostaleros y taberneros posean esclavos y esclavas, o contraten mozos. Dedicados al servicio doméstico, también seguramente cumplieron con la función de cuidar a los huéspedes, aunque no tengamos detalles explícitos de ello ${ }^{44}$.

La documentación nos muestra que, lejos de rechazar al enfermo, hombre o animal, que llegaba al hostal, estos lugares se convirtieron en un espacio donde las prácticas médicas fueron habituales ${ }^{45}$. Un espacio que, aunque sea desde esta perspectiva, pone en entredicho la fama de lugar donde viven personas de poca honestidad que cobijan individuos marginales. Tampoco debemos pecar de pensar que aquella atención médica fue estrictamente una cuestión de caridad. Seguramente detrás hubo algún tipo de beneficio económico que tan solo podemos imaginar.

\section{Cirujanos y BARberos EN El hostal}

La explicación de por qué el hostal se convirtió en un espacio donde se proporcionaba atención médica es diversa. En primer lugar, porque la amplia y diversa población flotante que recalaba en muchas ocasiones en estos lugares llegaba a sus destinos con las fuerzas justas y con la necesidad de reponerse de las difíciles condiciones en que se desarrollaban los fatigosos viajes. En caso de caer enfermo, se podía descansar y recuperarse de los acha-

\footnotetext{
${ }^{44}$ F.J. Marzal, La esclavitud en Valencia, pp. 663, 676, 682, 707 y 790. En el hostal valenciano de l'Àngel tenían un mozo llamado Antoni, que fue acusado de un hurto de ropas. ARV, Governació, Litium, nº 2312, mano 23, ff. 21-44 (20-9-1464).

${ }^{45}$ La presencia en el inventario del hostal de Domingo Conill de "una ampola ab una pocha d'ayga nafa", agua de azahar, usada como antiespasmódico, nos muestra la presencia de un medicamento habitual de la época, aunque no podamos confirmar si se usó también con la clientela.
} 
ques. Esto incluía incluso a hombres de iglesia. Así, cuando Pedro el Ceremonioso otorgó los capítulos de la cofradía de la catedral de Valencia en honor a Santa María, integrada por presbíteros y clérigos, se indica que si alguno de ellos se encontrara enfermo en hostal, espital o loch dins la ciutat, que los dos mayorales acudiesen a ver si necesitaba la atención de un médico o cualquier otra persona que le ayudara hasta su curación o su muerte ${ }^{46}$. En estos lugares se podía descansar, pernoctar, comer y, sobre todo, beber abundantemente, además de compartir veladas de juego con apuestas. Viajeros de la más diversa condición se juntaban con una población proclive a las peleas y las refriegas violentas, que acababan frecuentemente con heridos que debían ser atendidos. Si a esto añadimos la prostitución que se cobijaba en los hostales, con sus corolarios -los malos tratos a las mujeres y las habituales peleas entre rufianes o entre éstos y sus clientes-, no es de extrañar que las heridas fueran inevitables y el recurso a la cirugía frecuente ${ }^{47}$. No resulta pues extraño que el practicante de la medicina más común en el marco del hostal fue el barbero-cirujano, sin duda el profesional sobre el que recayó la mayor parte de las acciones terapéuticas en el mundo bajomedieval. Era lógico que en un ámbito donde los problemas de salud eran consecuencia de traumatismos, heridas o afecciones leves, fueran barberos o cirujanos quienes se ocuparan de los mismos. En realidad, la presencia del físico, el practicante de la medicina de mayor entidad, prestigio y formación, fue excepcional. Y seguramente la sordidez de algunos hostales y la naturaleza de los clientes estuvieron entre las causas de su ausencia.

Durante los primeros años del siglo $\mathrm{XV}$, y especialmente a mediados de siglo, la barbería se había convertido, en la ciudad de Valencia, en un oficio con un contingente de practicantes muy numeroso y con dificultades de integración. Su progreso socioeconómico había sido prodigioso, gracias a un amplio conjunto de factores -larga presencia y tradición en la ciudad, organización en forma de cofradía y después de arte, aumento de sus conocimientos teóricos y prácticos en medicina y cirugía, falta de personal médico después de la expulsión de los judíos, aumento de población en Valencia-que propiciaron, por un lado, la llegada de inmigrantes para practicar la barbería en la capital del Turia y, por otro, que algunas familias vieran en su ejercicio una buena opción de futuro para sus hijos. Ante la gran competencia, muchos barberos no pudieron acceder fácilmente al matrimonio ni tampoco les fue posible abrir un obrador propio debido al precio de las dotes, inaccesible para muchos, y a la necesidad de un capital inicial para abrir un negocio.

\footnotetext{
${ }^{46}$ ACA, C, reg. 920, f. 181 (10-6-1373).

${ }^{47}$ Este género de violencia en los espacios donde se ejercía la prostitución ha sido señalada por M. S. Mazzi, Prostitute e lenoni, pp. 372-380.
} 
Un grupo importante se vio desviado hacia la marginalidad y a moverse en los ambientes más sórdidos, cuando no a involucrarse en luchas de bandos o simplemente a engrosar las filas de la delincuencia ${ }^{48}$. Sin duda fueron los hostales, y particularmente los hostales del burdel, uno de estos ambientes. La relación de barberos con prostitutas era frecuente y verlos inmersos en este ambiente del prostíbulo también ${ }^{49}$. Así, el barbero Safont era acusado, junto a una prostituta del hostal de Joan el Coso, llamada Elvira, de haber herido a Lluís de Rotllanes delante del obrador de otro barbero llamado Joan, que tenía precisamente su negocio en el cruce del burdel (lo barber qui stà a la crohellada del bordell) ${ }^{50}$. En el hostal de Alfonso de Silla, en el camino a Quart, fue encontrado un barbero oriundo de Barcelona herido de una estocada en la cabeza. Había sido agredido por otro barbero llamado Bernat, también nativo de Barcelona. Estamos hablando, por tanto, de barberos inmigrantes que trabajaban en obradores ajenos; el primero en el de Manuel Blasco y el segundo en el de Antoni $\mathrm{Caro}^{51}$. Sin duda, estos casos nos hablan de personajes vinculados al hostal no como consecuencia de su dedicación profesional sino por circunstancias vitales particulares.

Producto de la presencia y la relación entre barberos y hostaleros fue la confianza. Así, un barbero sevillano llamado Alfonso de Porras nombró procurador al hostalero valenciano Joan de Bellmunt para que recuperara los cinco florines que le debía una hostalera llamada donya Elsa. Con todo, no podemos dejar de pensar en una posible estancia de Porras en el hostal de Bellmunt y de ahí la confianza en aquel para recuperar el dinero ${ }^{52}$.

Los hechos demuestran que los practicantes de la medicina encontraron en los hostales una clientela a la que atender. Así, por ejemplo, en cierta ocasión los cirujanos Ramon de Facs, Joan Ferragut i Francesc Trepat acudieron al hostal de la Corona, a instancias de Gilabert Sanoguera y su hijo, a examinar el estado de salud de Antoni, criado de Joan de Mur, un ciudadano de Zaragoza que residía temporalmente en aquel hostal. El mozo había sido

\footnotetext{
${ }^{48}$ C. Ferragud, Els barbers, pp. 42-44.

${ }^{49}$ En otros lugares de Europa se han podido localizar barberos ejerciendo de rufianes, aspecto éste que sospechamos fue también una realidad en la Valencia bajomedieval. No en vano, el de barbero es un oficio que pone en relación a muchos hombres. H.C. Peyer, Viaggiare nel medioevo, p. 46. En Florencia se documentan dos barberos y un albéitar que ejercieron de rufianes en la segunda mitad del siglo XV. Otros barberos florentinos se vieron involucrados en brutales agresiones a prostitutas. M.S. Mazzi, Prostitute e lenoni, p. 313, 373 y 378. Entre los proxenetas de la ciudad de Barcelona (alcavots) no vinculados al burdel, y por tanto ilegales, que fueron expulsados de la ciudad entre 1401 y 1469, había 33 barberos, el oficio más numeroso. R. Benito Julià, Les expulsions d'alcavots, tafurers $i$ vagabunds, p. 372.

${ }^{50} \mathrm{ARV}, \mathrm{JCr}, \mathrm{n}^{\circ} 22$, mano 3, s.f. (8-4-1445).

${ }^{51}$ ARV, JCr, $n^{\circ} 19$, mano 7, s.f. (20-7-1422).

${ }^{52}$ ARV, Protocolos, $n^{\circ} 2415$, ff. 324v-325 (28-8-1414).
} 
herido en la cabeza de dos cuchilladas, seguramente en alguna reyerta de las tan frecuentes entre los jóvenes de la ciudad, pero en aquel momento se había ya restablecido y no había peligro para su salud ${ }^{53}$.

No era extraño que los hostaleros ejercieran alguna actividad paralela, además de las ya citadas anteriormente de carácter comercial. En este sentido, se han documentado en diferentes estudios, fundamentalmente en el ámbito francés, hostaleros que también ejercieron de tabernero, notario, mercader, vendedor de esclavos, mulero, zapatero, albañil, banquero o agricultor ${ }^{54}$. En todo caso, sí parece que su participación en las funciones públicas de gobierno fue limitada, y en algunas ocasiones prohibida ${ }^{55}$. De hecho, por ejemplo, entre 1283 y 1516 los hostaleros no tuvieron ninguna representación en el consejo municipal de la ciudad de Valencia, y tampoco nos consta que tuvieran organización gremial ${ }^{56}$. Sin embargo, en los estudios ambientados en otros espacios europeos no se recogen noticias de individuos vinculados con la práctica de la medicina, humana o animal, a diferencia de lo que hemos podido documentar en el caso catalanoaragonés. Es posible que algunos de estos hostaleros se dieran cuenta de que tener conocimientos sanitarios podía resultar de gran utilidad y que con ellos podían conseguir beneficios complementarios. Esto debió ser así en el caso de la barbería. En el hostal se podría proceder al aseo de la clientela, con el corte de pelo y rapado de barbas, así como a la asistencia médica que los barberos practicaban. Conocemos un caso de la ciudad de Valencia: Jaume Vila, hostaler o barber, según reza en la documentación, intervino ante la justicia en cierta ocasión a favor de una prostituta llamada Leonor la Saragossana ${ }^{57}$.

En determinadas circunstancias podemos observar un vínculo más estrecho entre hostaleros y practicantes de la medicina, aunque no hay duda de que estos datos deben ser tomados con cautela, pues solo nos indican tendencias que apuntan hacia una posible realidad, la de la relación social y eco-

${ }^{53} \mathrm{ARV}, \mathrm{JCr}, \mathrm{n}^{\circ} 23$, mano 6, s.f. (26-11-1449).

${ }^{54}$ J.L. Picherit, L'hôtellerie, les hôteliers et hôtelières, p. 305. Bernat Saragossà abandonó su oficio de pelaire para convertirse en hostalero en Valencia. ARV, Protocolos, $n^{\circ} 2430$, f. 105 (4-5-1433). No obstante, en opinión de Peyer, los hostaleros no solían desarrollar otros oficios. H.C. Peyer, Viaggiare nel medioevo, p. 252.

${ }^{55}$ Algún autor ha señalado que desempeñaban cargos públicos. H.C. Peyer, Viaggiare nel medioevo, p. 252. Solamente conozco una noticia, procedente de Vila-real, sobre la prohibición de ejercer cargos: "Ítem, a 3 de octubre de 1509, establiren e ordenaren que ningun hostaler de la dita vila, així de correus com altres, no puxen entrar en los oficis de la vila". Ordenances municipals de Vila-real, p. 17.

${ }^{56}$ Agradezco a Rafael Narbona Vizcaíno, buen conocedor de la organización política y administrativa de la ciudad de Valencia, sus comentarios al respecto. R. Narbona, Gobierno político y luchas sociales.

${ }^{57} \mathrm{ARV}, \mathrm{JCr}, \mathrm{n}^{\circ} 19$, mano 7, s.f. (15-7-1422). 
nómica entre ambos grupos, producto de las prácticas médicas realizadas en los hostales, o bien por otras muchas razones. El que mantengan relaciones hostaleros y practicantes de la medicina no tiene porque tener una connotación diferente a aquella relación que puedan tener por ejemplo con notarios o con cualquier artesano. Pero nos resistimos a verla como meramente casual, a tenor de lo que se ha venido diciendo.

Se pueden encontrar diversos testimonios de esta relación en la documentación. Clara, la viuda del médico Bernat d'Artesa, reconoció que el hostalero Joan Burgés, del grao de Valencia, le pagaba anualmente un censo de 12 libras $^{58}$. También, cuando el justicia civil de Valencia ordenó tomar bienes al hostalero Joan Llorenç por una deuda contraída con un mercader, fue un cirujano llamado Llorenç Ballester el que se comprometió en la fian$\mathrm{za}^{59}$. El tabernero de la ciudad de Valencia Miquel Roig puso a su hijo Pere como aprendiz en un contrato (afermament) con el barbero Alfons Morera, durante tres años ${ }^{60}$. Pero los ejemplos más significativos que he localizado proceden, sin embargo, de Barcelona. Éstos ilustran adecuadamente la idea de la vinculación entre algunos practicantes de la medicina y los hostales. Así, el año 1363 uno de los impuestos de la ciudad de Barcelona (les leudes del pex e de les olles de la dita ciutat) será adquirido por el hostalero Pere Sacort y el barbero Simó Guardiola durante dos años y por un precio de 400 sueldos ${ }^{61}$. La familia Casals (Guillem, Nicolau y Francesc), barberos de Barcelona, venderán una mojada de viña situada en el lugar llamado Torrent Pregon, al hostalero de la misma ciudad llamado Ramon Andor, por un precio de 955 sueldos $^{62}$. En 1376, Antoni Pisà, barbero de Cagliari (Cerdeña),

${ }^{58}$ ARV, Protocolos, $n^{\circ} 2726$, s.f. (1-3-1421).

${ }^{59} \mathrm{ARV}, \mathrm{JCv}, \mathrm{n}^{\circ}$ 394, mano 3, f. 12 (3-4-1378). Llorenç Ballester fue un cirujano de la ciudad de Valencia del que tenemos escasas referencias. Estuvo casado con una tal Clareta y tuvo un hermano llamado Pere, que también fue cirujano. Fue examinado por Nicolau Barceló, y por tanto disponía de licencia para ejercer la medicina. ACA, C, reg. 940, f. 116 (25-9-1382). Poseía algunas casas en la parroquia de Sant Llorenç, por las que mantuvo un pleito. ACA, C, reg. 1782, ff. 112r-v (9-8-1374). Tan solo contamos con un par de referencias más relativas a una pensión que debía junto con su hermano y su cuñada y otros dos matrimonios. ARV, Protocolos, $n^{\circ} 2642$, s.f. (24-10-1392); n 2643, s.f. (28-5-1399).

${ }^{60}$ En el contrato, que siguió el patrón habitual de todos los contratos de afermament, no se especificó que éste tuviera que aprender el oficio de barbero, sino que simplemente le haría de criado (mancipium). En acabar el periodo del contrato el chico recibiría "unam tunicam forratam de pellibus corderinarum albarum et unum capucium et unum par caligarum panni lane novi valoris undemcim vel duodecim solidorum per alna et unam diplohidem sive jupó novam cotonine albe." ARV, Protocolos, nº 2426 (30-9-1429).

${ }^{61}$ ACA, RP, MR, no 994, f. 11v.

${ }^{62}$ ACB, Protocolos, $n^{\circ} 185$, s.f. (3-10-1370). Venta confirmada posteriormente por Francesca, esposa de Nicolau Casals. ACB, Protocolos, $\mathrm{n}^{\circ} 188$, s.f. (20-9-1371). El barbero Guillem de Casals, miembro de la casa real, era el padre de los también barberos Francesc y Nicolau. Aunque Nicolau parece ser el hijo mayor y era conocido como cirujano ya en 
debía 36 sueldos al hostalero de Barcelona Francesc Amorós por el precio de algunos objetos ad opus offici mei barbitunsorie. Pisà los había adquirido para embarcarse en la coca de Pere d'Urgell en un viaje por Cerdeña, Sicilia y Calabria y devolvería el dinero cuando el barco regresara a Barcelona ${ }^{63}$.

Anteriormente hemos hablado de la prostitución practicada en los hostales del burdel de Valencia. Pues bien, en las primeras décadas del siglo XV empezó a tenerse en cuenta la necesidad de practicar revisiones médicas a las mujeres que ejercían la prostitución. En los capítulos de 1422 de la Confraria de Nostra Senyora dels Innocents i Desemparats se había acordado la asistencia religiosa durante la enfermedad y el entierro de los cadáveres de las prostitutas, caritativamente consideradas como cofrades. Aunque su principal objetivo estribaba en la "conversión" de éstas, también se atendían sus necesidades materiales, en particular durante su enfermedad, ofreciéndoseles tratamientos apropiados. Se estableció por ello una colecta de un dinero semanal que pagaban los domingos todas las pupilas y que era administrada por los hostaleros o dueños de las casas de la mancebía. Desde 1430 se conservan pagos consignados a médicos, cirujanos y barberos que habían atendido a algunas de estas mujeres, así como el pago por medicamentos utilizados o los gastos hospitalarios ${ }^{64}$.

Como hemos advertido, la preocupación por la salud de las prostitutas no fue una novedad del siglo XVI, aunque así parezca deducirse de los trabajos que se han ocupado de este tema. Sin embargo, a finales del siglo XV, con la aparición y extensión de la sífilis, conocida en Valencia como el mal de

1362, será Francesc quien alcanzará una mejor posición. Efectivamente, formó parte de la casa real al menos durante los periodos 1373-74, 1379-80 y 1383-84, cuando recibió diversos pagos (quitacions) por sus servicios. ACA, RP, MR, $\mathrm{n}^{\circ} 2477$, ff. 44, 59 y 93; 2478 , ff. 40 v y $62 ; 2479$, ff. 34 y 68 . ACA, RP, Tesorería del Rey, no 372 , f. $91 \mathrm{v}$; ibidem, $\mathrm{n}^{\circ} 378$, f. 154 (1384); ibidem, $\mathrm{n}^{\circ} 364$, f. 149. La viña vendida al hostalero formaba parte del lote de propiedades, que incluían dos casas y un esclavo, con las que Guillem vistió la emancipación de su hijo el 13 de octubre de 1367 (ACB, Protocolos, $\mathrm{n}^{\mathrm{o}}$ 107, ff. 75r-v). Unos meses antes, Francesc había aceptado un aprendiz (ACB, Protocolos, n 107 , f. 23 , 12-5-1367). Esta tierra había sido, por tanto, parte del patrimonio de estos barberos hasta que decidieron deshacerse de ella.

${ }^{63}$ AHPB, Pere Martí, "Llibre comú", 12-VIII-1366/8-III-1367, f. 66v (7-11-1376). Sobre los barberos y sus actividades en las galeras y embarcaciones diversas, véase Ll. Cifuentes, $\mathrm{La}$ medicina en las galeras, pp. 1-15 También podemos citar otros ejemplos de la relación entre hostaleros y diversos profesionales de la sanidad barceloneses. Así, Elisenda, la esposa del boticario barcelonés Bernat Catllús, junto con Guillamoneta, la esposa del sastre Bernat Mulet, hicieron procurador al hostalero Berenguer de Cases. AHPB, Bartomeu Eiximenis, "Manual", 30-XII-1377/24-XII-1378, f. 6v (30-1-1378). El físico-cirujano Berenguer Batlle hizo procurador al hostalero Bernat de Ties. AHPB, Berenguer Ermengol, "Llibre comú", 11-IV-1375/10IX-1375, f. 79v (12-7-1375).

${ }^{64}$ J. Rodrigo Pertegás, Historia de la antigua y real Cofradía, pp. 109-112. Se trata de los casos del médico mestre Albesa (1430), del barbero Antoni Pometa (1458), de Francesc Adalid (1461) y del cirujano mestre Domingo (1461). 
siment, el control médico se incrementó ante el riesgo de contagio y el miedo al desarrollo de esta nueva enfermedad ${ }^{65}$.

Ya por aquellos años causaba cierta admiración la organización del burdel, incluido el control sanitario de las prostitutas. Así lo manifestó en 1501 Antoine de Lalaing, señor de Montigny, quien acompañó durante un viaje a Felipe el Hermoso:

Hay dos médicos encargados y pagados por la ciudad para visitar todas las semanas a las mujeres, para saber si hay algunas enfermas, con pústulas u otras enfermedades secretas, para retirarlas de aquel lugar. Si hay allí alguna enferma de la ciudad, los regidores tienen un sitio para atenderlas, a su costa, y las forasteras son enviadas a donde quieran $\operatorname{ir}^{66}$.

\section{El HOSTAL Y LA ATENCIÓN A LOS EQUINOS ENFERMOS}

Que en un hostal podían reposar a diario un buen número de caballerías lo corrobora el ejemplo del hostalero de la ciudad de Valencia Gonçalbo Ferrández. Éste vendió a un campesino llamado Martí d'Amelles todo el estiércol (omnia stercora bestiarium pro septem sive stablies illus hostales) que produjera su establecimiento durante un año por un precio de 12 florines. Martí se comprometió a satisfacer el precio parcialmente en vino, producto que también sería bien recibido en el hostal, y otra parte en moneda, y Ferrández prometió guardar todo el estiércol y no venderlo a nadie más ${ }^{67}$. Es un ejemplo más de la estrecha relación entre la ciudad y el mundo agrario de sus contornos, que se abastecen de un bien tan preciado como el estiércol para sus campos en establecimientos donde abunda.

Pero no necesariamente el trato con animales se reducía a los equinos con que llegaban los clientes al hostal. El hostalero valenciano Joan Péreç vendió a un cambista llamado Francesc Siurana 35 arrobas de lana mei cabanis bestiaris lanaris, lanam bonam mercantibiliem et receptibilem faldatam et stuxatam, squilatam in die claro et sereno, et triatam a pilo canino et erba grossa, por un precio de 20 florines. El hecho de que un hostalero poseyera una cabaña de ganado lanar y que se dedicara a la venta de esta materia prima,

\footnotetext{
${ }^{65}$ M. L. López Terrada, El mal de siment en la Valencia del siglo XVI, pp. 139-142.

${ }^{66}$ J. García Mercadal (ed.), Viajes de extranjeros por España y Portugal, p. 447. También se conservan los pagos a médicos que atendieron a estas prostitutas durante el siglo XVI. M. Carboneres, Picaronas y alcahuetas, p. 95.

${ }^{67}$ ARV, Protocolos, $n^{\circ} 2414$, ff. 157v-158 (10-3-1413)
} 
ya preparada, no deja de llamar la atención sobre sus actividades, sus posibilidades económicas y su posición social ${ }^{68}$.

Tal como ocurrió con sus clientes, algunos hostaleros combinaron su quehacer con la actividad de atender a los animales con los que se desplazaban los viajeros. Reponer herraduras, curar alguna herida o sanar alguna enfermedad contraída por los caballos era trabajo propio de herreros y, especialmente, albéitares (menescals en la Corona de Aragón) ${ }^{69}$. Tal como ocurrió en el caso de la medicina humana, algunos hostaleros procedían de un oficio vinculado al mundo de la sanidad, en este caso animal, e incluso compaginaron éste con el regimiento del hostal. Este fue el caso de Domènec Alberó, en Montcada (Cataluña), quien, durante la segunda mitad del siglo XIV, compaginó algún tiempo su trabajo de herrero con el de hostalero ${ }^{70}$.

No era extraño que los animales quedaran como garantía de pago por deudas (penyores) en el hostal. La confianza depositada en los hostaleros, como personajes de los que se podía esperar honestidad por parte de sus clientes, se hace evidente en estos casos ${ }^{71}$. Así, por ejemplo, Aparici Carbonell, un campesino de Campanar, en la huerta de Valencia, fue asaltado y acuchillado por el especiero Fernando Pomar y su hijo cuando se dirigía en compañía de un saig (sayón) por el camino de Sant Vicent a incautar un rocín en el hostal conocido con el nombre de Llobregat ${ }^{72}$. No hay duda de que un personaje bien acostumbrado a recibir y alojar todo tipo de equinos como el hostalero debía conocer bien las características propias de un buen animal y los signos propios de sus enfermedades ${ }^{73}$.

Hostaleros y albéitares fueron personajes considerados de gran relevancia dentro de la dinámica económica urbana. Junto con otros artesanos relacionados con el metal y el trato con animales (herreros, fabricantes de frenos para caballos, cuchilleros, muleros), con los oficios que se dedicaban a abastecer de pan (molineros, horneros), con barberos y con individuos con una formación técnica y experta en letras (escribanos, notarios, juristas), hostaleros y albéitares fueron considerados indispensables para el buen funcionamiento de la sociedad. Por eso, cuando Pedro el Ceremonioso decretaba la movilización de los ciudadanos usando el princeps namque, a petición de

${ }^{68}$ ARV, Protocolos, $\mathrm{n}^{\circ}$ 2415, ff. 360v-361 (14-9-1414).

${ }^{69}$ Ll. Cifuentes, C. Ferragud, L. Garcia Ballester, Els menescals i l'art de la menescalia, p. 88.

${ }^{70}$ R.A. Banegas, Un caso de hostal de carretera catalán, p. 66.

${ }^{71}$ H.C. Peyer, Viaggiare nel medioevo, p. 260.

${ }^{72} \mathrm{ARV}, \mathrm{JCr}, \mathrm{n}^{\circ} 42$, s.f. (19-10-1396).

${ }^{73}$ No deja de resultar interesante el hecho de que en el famoso relato de los Cuentos de Canterbury el narrador describa con especial atención las cabalgaduras sobre las que llegaban todos los viajeros al hostal. G. Chaucer, Contes de Canterbury, pp. 12-13 y 23. 
algún gobierno municipal, por ejemplo en el caso de Tarragona, permitió que determinados individuos que practicaban estos oficios permanecieran exentos de participar en las campañas militares ${ }^{74}$.

Como ocurrió con las sospechas, a veces bien fundadas, sobre el hostalero, a quien se acusaba de su posición privilegiada para hacer buenos negocios, capaz de cometer ciertos abusos, también podemos sospechar que su relación con los albéitares pudo aprovecharse para conseguir algunos ingresos adicionales ${ }^{75}$. De esta forma, el hostalero podría proporcionar a un albéitar una clientela segura y habitual.

Ante un animal que no resiste un viaje, como consecuencia del cansancio y las enfermedades, no queda otra alternativa que dejarlo para que se recupere y luego volver a buscarlo. El peligro reside en que uno puede venir de muy lejos y pasará mucho tiempo hasta que pueda regresar a la ciudad donde depositó su animal para recuperarlo. Era entonces cuando el hostalero podía cometer ciertos abusos, como nos confirman algunos ejemplos entresacados de la documentación real, y enmarcados geográficamente en diversos puntos de la Corona de Aragón.

En cierta ocasión, el infante Juan escribió al justicia de la villa de Fraga para reclamar la devolución de un rocín del caballero Jacques de Monmor que había sido dejado al hostalero de la villa, Bernat Conesa, por el cansancio y enfermedad que arrastraba el animal ${ }^{76}$. El equino debía ser cuidado y posteriormente el caballero enviaría a su escudero para recuperarlo. Las exigencias monetarias del hostalero, sin embargo, parecían exageradas y además se le acusaba de haberse beneficiado del animal, pues lo había alquilado diversas veces. El infante pedía al justicia un arbitrio que satisficiera rápidamente ambas partes.

En otro caso, cuando en julio de 1379 se solicitó al rey Pedro el Ceremonioso por parte del tesorero real Pere de Pla, residente en Montpellier, una indemnización por dos mulas muertas por la enfermedad de cucas -nada menos que 100 y 90 florines-, se acudió a los testimonios jurados de albéitares y hostaleros (iuxta depositiones medio iuramento factas per quosdam menes-

\footnotetext{
${ }^{74}$ ACA, C, reg. 906, ff. 20v-21 (21-8-1368).

${ }^{75}$ En Montpellier el hostalero Etienne Bozon adquirió la tasa de doce dineros por libra que debían pagar los albéitares y los herreros de la ciudad. J. Combes, Hoteliers et hotelleries de Montpellier, p. 67. Las ordenanzas de la cofradía de San Eloy de Zaragoza, que aglutinaba a herreros y albéitares, prohibían que ninguno de sus miembros pudiera desplazarse a un hostal para herrar sin ser llamado previamente por el hostalero o el propietario del animal, bajo multa de 10 sueldos. S. Lozano, Las ordenanzas de la cofradía, p. 226.

76 "una haca sua per cansament o accident que li vench, pregan-lo qu·en pensàs covinentment e que no la liuràs sinó a ell matex o a Haurí de Frare, escuder seu". ACA, C, reg. 1674, f. $37 \mathrm{r}(8-5-1368)$.
} 
callos, hostalerios et alios locorum Montispesulani), que fueron recogidos ante notario en sendos documentos ${ }^{77}$. También se pidió al baile de Cervera (Cataluña) que investigara el caso de Guillem Pagès, un miembro de la corte que durante las Navidades había dejado un rocín enfermo en manos del hostalero Duran de Puig y del menescal Bernat de Grimosacs, ambos habitantes de la villa de Cervera, para que lo sanaran, alimentaran y cuidaran hasta que fuera recogido. Todo aquello sería después saldado por Pagès cuando fuera recuperado el animal. Sin embargo, se procedió a una subasta pública del rocín para pagar estos gastos, seguramente porque su propietario prefería adquirir otro animal ${ }^{78}$.

Bernat Roig era un ciudadano de Barcelona que recurrió al gobernador de la ciudad de Valencia para resolver un asunto relativo a una mula enferma que había sido alquilada a un tal Gilabert, hostalero barcelonés ${ }^{79}$. El animal enfermó cuando Roig llegó a Valencia, de tal manera que había sido imposible devolverla debido a que todavía no se había restablecido, a pesar de las atenciones de los albéitares. Roig pidió al gobernador que recogiera el testimonio de los profesionales que habían atendido la mula y fuera enviada una notificación al respecto al veguer de Barcelona. De este modo, Joan de Prades, albéitar de la ciudad, fue interrogado sobre el asunto y explicó como Bernat Roig le había encargado curar a la mula que yacía enferma (haja plagues en les anques) en el hostal de Martí Alberó ${ }^{80}$. A continuación, el hostalero confirmó lo ocurrido:

lo qual dit mul lo dia que entrà e fon mès en lo seu hostal era sans e bo segons ell, testimoni, vehé. Et seguins en aprés que en lo dia de aprés següent lo dit en Bernat Roig per lo matí entrà en lo stable per dar civada al dit mul e troball ab la una cuxa o anca inflada e de

\footnotetext{
${ }^{77}$ ACA, C, reg. 1349, ff. 19v-20r (27-7-1369).

78 "dumisset quendam ronsinum infirmum in posse hostalerii et menescalli predictorum, quem ronsinum ipsi hostalerii et menescalii ad eorum propriis sustentarunt et omnia sibi necessaria amministrarunt usque in diem presentem ipso Guillelmo promitente eisdem safisfacere in laboribus et expensis occasione infirmitate roncini eiusdem factis et fiendis ac sustinendis". ACA, C, reg. 1267, f. 183r (11-8-1380).

${ }^{79}$ Los hostaleros también ejercieron la labor de alquiler de animales. En Montpellier el albéitar Jean Cavalié estaba encargado de percibir el impuesto que gravaba la venta de animales J. Combes, Hoteliers et hotelleries de Montpellier, p. 67. Entre las ordenanzas de la ciudad de Barcelona relativas a hostaleros, fechadas en 1460, figura el Capítol del manasqual. Según esta normativa cualquier persona que alquilara alguna bestia estaba obligada a encontrar rápidamente un albéitar (menescal) en cuanto se diera cuenta de que el animal estaba enfermo. En este sentido, era importante discernir si el animal había enfermado durante el viaje o ya lo estaba antes de emprenderlo. También se recogía la obligatoriedad de tener cuidado de no perjudicar a los animales y alimentarlos correctamente con la cantidad apropiada de cebada. J.L. Martín, "Ordinacions dels hostalers, taverners e aventurers", p. 82.

${ }^{80} \mathrm{Sin}$ parentesco aparente con los hostaleros catalanes anteriormente citados.
} 
mal tempre, e ell, testimoni... pregat per lo dit en Bernat Roig que li mostràs un bon menescal, féu venir al dit seu hostal mestre Johan de Prades, menescal, que pensàs del dit mul.

De cualquier forma, quedaba claro que la enfermedad no había aparecido por negligencia de Roig sino por accidente ${ }^{81}$.

\section{ENFERMO EN CASA AJENA}

El 6 de junio de 1360, se presentó ante el justicia civil de la ciudad de Valencia el mercader de Mallorca Joan Sobirós ${ }^{82}$. Éste denunció a Sibil.la, la esposa de un corredor llamado Bernat Gargila, de haberle sustraído 100 sueldos de una bolsa que había dejado encomendada en su casa, con un contenido de 800 sueldos. Sobirós pedía la restitución de la cantidad. La contestación llegó el 7 de julio de parte del notario Berenguer Guitart, en representación de la acusada. Fue entonces cuando el procurador explicó la causa de esta sustracción. Sibil-la había tomado aquel dinero en pago por los servicios que le habían prestado a Sobirós dos años antes, durante cuatro meses, los dos que permaneció enfermo en aquella casa y otros dos recuperándose de la enfermedad.

Efectivamente, según parecía, el mercader mallorquín había llegado a Valencia procedente de Cataluña. Entonces pidió quedarse o posar en casa de Sibil.la. El caso que aquí nos ocupa evidencia una realidad común en la Europa bajomedieval, esto es, la convivencia de una hospitalidad privada, que tenía orígenes remotos en el tiempo, con una hospitalidad profesional que se fue gestando en los siglos bajomedievales. Por aquel entonces, cualquier casa, en el campo o en la ciudad, podía alojar a gente de procedencia, ocupación y condición diversas, de tal forma que toda la ciudad era una gran taberna u hostal, un microuniverso donde podían proliferar los intercambios comerciales, un pequeño mercado a cubierto, bajo la tutela y procura del dueño. En determinadas épocas del año, por ejemplo con la llegada de las ferias y la afluencia de mercaderes a la ciudad, resultaba insuficiente la oferta de hostales y entonces la hospitalidad privada era un buen complemento.

Otra cuestión sería cómo se identificaban estas casas que ofrecían alojamiento ${ }^{83}$. Tal vez existía ya una cierta confianza con la familia de acogi-

\footnotetext{
${ }^{81}$ El documento ha sido trascrito en C. Ferragud, La cura dels animals, Apéndice 10.

${ }^{82} \mathrm{ARV}, \mathrm{JCv}, \mathrm{n}^{\circ}$ 231, mano 3, ff. 22r-v (16-6-1360).

${ }^{83}$ La casuística es muy variada según el escenario urbano o rural, mediterráneo o atlántico, e incluso dependiendo de regiones y ciudades. En cualquier caso, parece ser que la tendencia fue 
$\mathrm{da}^{84}$, aunque este no parece ser el caso, a tenor de las circunstancias del pleito. Todo parece indicar que Sobirós llegó posiblemente enfermo a recuperar el dinero que tenía depositado en aquella casa y solicitó albergue (preguà aquella que li ministre lit, statge e altres embaxes de casa per obs de cuyna, menjar, star e tot ço ab que mester hagués). Todo lo que pedía le fue concedido, a tenor del testimonio dado en el pleito. A Sobirós se le proporcionó una habitación apartada de la casa para que se le molestara lo menos posible, y se le preparó una cama con toda la ropa necesaria y en buen estado. Éste sufría de unas fiebres que le hacían sudar abundantemente y por eso, a parte de cambiarle la cama día y noche, cada tres semanas era necesario también lavar las sábanas. La mujer consideraba que el precio que hubiera pagado en un hostal por estar en tales condiciones no hubiera sido menos de 6 dineros diarios. Esto equivalía a unos 60 sueldos, más o menos, para los cuatro meses. Pero no solo se trataba del tiempo que había ocupado una habitación, sino también de la dedicación de Sibil-la y otras mujeres de la casa que habían atendido al enfermo, el cual necesitaba la presencia constante de al menos una persona. Esto había provocado que la mujer hubiese cesado en el trabajo de hilar lana, y lógicamente había perdido los ingresos producto de esta tarea ${ }^{85}$.

Otra de las atenciones necesarias para un enfermo era el cambio de dieta. Efectivamente, dentro del galenismo la comida tenía una importancia fundamental como la primera de las intervenciones terapéuticas en las que pensaba un médico, tanto para recuperar la salud como para mantenerla. Los principales y más influyentes textos médicos de la época defendieron estos principios galenistas, hasta el punto que el ilustre historiador Owsei Temkin llega a considerar a Galeno como un médico dietista ${ }^{86}$. Los caldos reconfortantes a base, sobre todo, de carne de gallina eran especialmente indicados, ya que se pensaba que nutrían bien, templaban los humores y se digerían con rapidez. Hay que decir, con todo, que estas comidas eran caras y no aptas para todos los bolsillos ${ }^{87}$. Aunque el empirismo resultaba fundamental en las prácticas médicas domésticas y populares, no hay duda de que esta forma de actuar que hemos comprobado frecuentemente, sugiere una penetración de los

a un aumento de la hospitalidad profesional por la transformación de las técnicas mercantiles, el crecimiento de la correspondencia comercial, el desarrollo de la letra de cambio y la menor movilidad de los mercaderes. H.C. Peyer, Viaggiare nel medioevo, pp. 235 y 238-242.

${ }^{84}$ G. Duby, Ph. Ariès (dirs.), Historia de la vida privada., p. 250.

${ }^{85}$ Como se ha indicado, muchas mujeres contribuían a los ingresos del hogar con su trabajo en el sector textil. La presencia de los elementos para hilar es muy frecuente en las casas. T. Vinyoles, Història de les dones, pp. 186-187.

${ }^{86}$ O. Temkin, Galenism. Rise and decline, pp. 38-40.

${ }^{87}$ P. Gil-Sotres, Regimen sanitatis, pp. 202-240; C. Ferragud, El metge sota sospita, pp. 74-75. 
conocimientos médicos en la sociedad ${ }^{88}$. Junto a estos cambios de dieta, se recomendaba la administración de las medicinas pertinentes, a menudo purgantes, como ocurrió con Sobirós:

Et axí que li avien a fer lo lit diverses vegades entre nit e dia, e cuynar-li viandes aportades de malalt e fer-li aygua cuyta... Et tenir-lo apper de nit e de dia. E costeir-lo en tota aquella manera que.s pertany a malalt.

Sibillla y sus compañeras habían atendido con tal consideración al mercader que entendían que en condiciones normales éste hubiera necesitado 8 dineros para pagar a una persona que ejerciera tales menesteres. A esto sumaban 40 sueldos que se calculaba había costado mantener encendida la cocina, con el consumo de leña y fuego correspondientes para prepararle los alimentos, así como todo lo necesario para la mesa y en general para hacer vida en la casa. En definitiva, las cuentas nos indican que los 100 sueldos habían sido tomados para satisfacer el pago que la mujer consideró justo, de acuerdo a sus atenciones.

Otro caso particularmente interesante lo encontramos en la ciudad de Xàtiva durante el año $1457^{89}$. Según los registros notariales de Francesc Saranyana, en la ciudad se alojaban una gran cantidad de mercaderes y campesinos que temporalmente se habían trasladado a ella para hacer negocios, vender sus productos o adquirir todo aquello que les hacía falta. Durante el tiempo que pasaban en la ciudad muchos residían en hogares privados. Tal fue el caso del castellano Diego de Toledo, vecino de Alcaraz, dedicado a la venta de textiles. En el mes de enero, acompañado por su hermano Rodrigo, estaba alojado en casa del notario Pere Vaello y, a través de éste, había entregado una suma a un corredor de la ciudad para que adquiriera en su nombre diversas mercancías, seguramente para llevarlas a la tienda que poseía en Alcaraz. Aquejado de una enfermedad que fue descrita como mal de coll, Diego fue visitado tanto por un médico, el mestre Lleó, que cobró 9 sueldos por su intervención, como por el barbero-cirujano Pere Guitart, que recibió 13 sueldos y 4 dineros, y contrató los servicios de la esposa del cuchillero Garcia Goçalvo para que atendiera sus necesidades. Sin embargo, su salud no debió mejorar y el día 9 de febrero reclamó la presencia del notario Francesc Saranyana. Diego designó como albacea a un tío paterno suyo, llamado Fernando, y expresó sus últimas voluntades.

\footnotetext{
${ }^{88}$ C. Ferragud, La atención médica doméstica, pp. 141-142.

${ }^{89}$ Debo agradecer a José María Cruselles el haber llamado mi atención sobre este documento, el cual él mismo ya utilizó, aunque no desde una perspectiva médica, en J.M. Cruselles, La sociedad bajomedieval.
} 
Debió morir unas horas después. Entonces se hizo inventario de las pertenencias del difunto: un caballo, algún dinero y mercancías diversas. Antes de regresar a Alcaraz con el cadáver, Fernando saldó las deudas contraídas por su sobrino en Xàtiva, las antes mencionadas de carácter médico, más 16 sueldos para el notario Vaello de posada, palla e civada, es decir, por pago de su estancia y la de su caballería, justo como solía ocurrir en cualquier hostal. Esta vez la resolución del pago se hizo de forma ordenada y sin ninguna objeción y problema por ninguna de las partes, si bien es cierto que en el primer caso analizado los gastos y trastornos ocasionados por el enfermo fueron mucho mayores.

\section{CONCLUSIONES}

Uno de los aspectos más complejos a los que se enfrenta el historiador de la medicina medieval es el relativo a la experiencia de enfermar y de cómo el enfermo buscaba y optaba por una atención médica oportuna, de entre toda la oferta que ofrecía el plural mercado asistencial tardomedieval. Si el estudio de esta realidad es complejo en las circunstancias habituales de la vida de una persona, más complejo resulta acercarse a los momentos en que alguien se encontraba lejos de su hogar y enfermaba. Sin embargo, los archivos valencianos y catalanes nos han facilitado materiales que nos permiten observar, aunque sea en imágenes aisladas, experiencias concretas del enfermar.

De esta forma hemos podido observar que, más allá de los espacios que fueron diseñados específicamente para sanar enfermos, las circunstancias obligaron a "improvisar" la atención médica de humanos y equinos -también grandes protagonistas de la historia, indispensables en la economía medieval, a los que aquí hemos querido dar cabida- en lugares de hospedaje temporal, desde los hostales, hasta allí donde normalmente tenían lugar los actos más frecuentes de curación de enfermos, los hogares particulares, que en ocasiones hospedaban extranjeros. Estos documentos confirman el papel determinante de la mujer en la atención médica doméstica dispensada a cualquiera que se encontrara bajo su mismo techo. Y, junto con ellas, la importancia clave de la figura del barbero como paraguas sanitario que cubrió la mayor parte de la atención médica durante la baja Edad Media. Pero también cómo esta ayuda se vio reforzada por la participación de cirujanos y, en menor medida, de físicos, que intervenían cuando se les requería y a cuyas órdenes se pusieron las mismas mujeres. 


\section{BIBLIOGRAFÍA CITADA}

Banegas, Ramón A., Un caso de hostal de carretera catalán durante el siglo XV: el hostal de la familia Alberó de Montcada, "Ex Novo: revista d'història i humanitats" 2 (2005), pp. 65-83.

Barceló, Maria, La talla de la ciutat de Mallorca, 1512, Palma de Mallorca, Universitat de les Illes Balears, 2002.

Beltrán, Rafael (ed.), Maravillas, peregrinaciones y utopías: Literatura de viajes en el mundo románico, Valencia, Publicaciones de la Universitat de València, 2002.

Benito Julià, Roger, Les expulsions d'alcavots, tafurers i vagabunds (14011469), "Acta historica et archaeologica mediaevalia" 29 (2008), pp. 369-394.

Berengo, Marino, L'Europa delle città: il volto della società urbana europea tra Medioevo ed Età moderna, Turín, Giulio Einaudi, 1999.

Brodman, James William, Charity \& welfare. Hospitals and poor in medieval Catalonia, Pennsylvania, University of Pennsylvania Press, 1998.

Cabré, Montserrat, Women or healers? Household practices and the cathegories of health care in late medieval Iberia, "Bulletin of the History of Medicine" 82 (2008), pp. 18-51.

Carboneres, Manuel, Picaronas y alcahuetas ó la mancebía de Valencia. Apuntes para la historia de la prostitución desde principios del siglo XIV hasta poco antes de la abolición de los fueros, Valencia, Imp. El Mercantil Valenciano, 1876.

Colón, Germà; Garcia, Arcadi (eds.), Furs de València, vol. II.València, Barcino, 1970.

Combes, Jean, Hoteliers et hotelleries de Montpellier a la fin du XIVe siècle et au XVe siècle, en Hommage à André Dupont, Montpellier, Federation Historique du Languedoc Mediterranéen et du Roussillon, 1974, pp. 55-81.

Chaucer, Geoffrey, Contes de Canterbury, Barcelona, Quaderns Crema, 1997.

Cifuentes, Lluís; Ferragud, Carmel; García Ballester, Luis, Els menescals $i$ l'art de la menescalia a la Corona d'Aragó durant la Baixa Edat Mitjana, en Història de la ramaderia i la veterinària als Països Catalans. IV Col-loqui d'Història Agrària (maig del 1997). Actes, Barcelona, Centre d'Estudis Històrics Internacionals - Universitat de Barcelona, 1999, pp. 75-98.

Cifuentes, Lluís, La medicina en las galeras de la Corona de Aragón a finales de la Edad Media: la caja del barbero y sus libros, "Medicina \& Historia" 4 (2000), pp. 1-15.

Cruselles, José María, Escuela y sociedad en la Valencia bajomedieval, Valencia, Diputació de València, 1997. 
Cruselles, José Maria, La sociedad bajomedieval en los registros notariales de Francesc Saranyana (Xàtiva, 1429-1462), en Idem; Pons, Vicent (eds.), Historia de Xàtiva, Publicaciones de la Universitat de València - Ajuntament de Xàtiva, vol. III, en prensa.

Duby, Georges; Ariès, Philippe (dirs.), Historia de la vida privada. Poder privado y poder público en la Europa feudal, vol. III, Madrid, Taurus,

Epistolari del segle XV. Recull de cartes privades, a cargo de Francesc Martorell, Barcelona, Barcino, 1926.

Establiments municipals del Maestrat, els Ports de Morella i Llucena (segles XIV-XVIII), ed. a cargo de Enric Guinot, Valencia, Publicaciones de la Universitat de València, 2006.

Ferragud, Carmel, Medicina i promoció social a la Baixa Edat Mitjana (Corona d'Aragó, 1350-1410), Madrid, CSIC, 2005.

Ferragud, Carmel, La atención médica doméstica practicada por mujeres en la Valencia bajomedieval, "Dynamis" 27 (2007), pp. 133-156.

Ferragud, Carmel, La cura dels animals. Menescals i menescalia a la València medieval, Catarroja, Afers, 2009.

Ferragud, Carmel, Els barbers de la ciutat de València durant el segle XV a través dels llibres del justícia criminal, "Anuario de Estudios Medievales" 41/1 (2011), pp. 31-57.

Ferragud, Carmel, El metge sota sospita. Actuació mèdica en els testimonis pericials a ferits davant la cort del justícia criminal de la ciutat de València (1396), "Recerques" 62 (2011), pp. 69-94.

Ferragud, Carmel, La atención médica de los animales durante la Baja Edad Media en los reinos hispánicos, "Medievalismo" 21 (2011), pp. 29-54.

Ferrer, Vicent, Sermons, a cargo de Schib, Gret, vol. III, Barcelona, Barcino, 1975; vol. V, Barcelona, Barcino, 1984.

Fresquet, José L.; López, M. Luz; Catalá, Jesús; Micó, Juan (eds.), Archivo Rodrigo Pertegás. Siglos XI-XV, Valencia, Universitat de ValènciaSantander, Fundación Marcelino Botín, 2002, CD-Rom.

García Ballester, Luis; McVaugh, Michael R. (eds.); Gil Sotres, Pedro (estudio y comentarios), Regimen sanitatis ad regem Aragonum. Arnaldi de Vilanova Opera Medica Omnia. X.1, Barcelona, Universitat de Barcelona - Fundació Noguera, 1996.

García Mercadal, José (ed.), Viajes de extranjeros por España y Portugal. Desde los tiempos más remotos hasta comienzos del siglo XX, vol. I, Salamanca, Junta de Castilla y León, 1999.

Gensini, Sergio (ed.), Viaggiare nel Medioevo, Pisa, Pacini editore, 2000.

Graullera, Vicente, Los hostaleros del burdel de Valencia, "Revista d'Història Medieval" 1 (1990), pp. 201-216. 
Graullera, Vicente, Delito de sodomía en la Valencia del siglo XVI, "Torrens" 7 (1991-93), pp. 229- 233.

Gual Camarena, Miguel, El hospedaje hispano-medieval: aportaciones para su estudio, "Anuario de Historia del Derecho Español” 32 (1962), pp. 527-542.

Horden, Peregrine, Household care and informal networks. Comparisons and continuites from antiquity to the present, en Horden, Peregrine y Smith, Richard (eds.), The Locus of Care. Families, communities, institutions and the provision of welfare since antiquity, Londres, Routledge, 1998, pp. 21-67.

Libre de diversos statuts e ordenacions fets per lo consell de la vila de Algezi$r a$, ed. a cargo de Aureliano Lairón Pla, Valencia, Publicaciones de la Universitat de València, 2000.

Le Goff, Jacques, Oficios lícitos e ilícitos en el Occidente medieval, en Tiempo, trabajo y cultura en el Occidente Medieval, Madrid, Taurus, 1983, pp. 86-102.

López Terrada, M. Luz, El mal de siment en la Valencia del siglo XVI: imágenes del morbo gallico en una ciudad mediterránea europea, "Dynamis" 11 (1991), pp. 119-146

Llibre d'establiments $i$ ordenacions de la ciutat de València (1296-1345), ed. a cargo de Antonio Furió; Ferran García-Oliver, vol. I, Valencia, Publicaciones de la Universitat de València, 2007,

Lozano, Susana, Las ordenanzas de la cofradía de Sant Eloy de los herreros y menescales de la ciudad de Zaragoza del año 1459, "Aragón en la Edad Media” 22 (2011), pp. 213-228.

Martín, José Luis, "Ordinacions dels hostalers, taverners e aventurers" de Barcelona a fines del siglo XV, en Miscel-lània en homenatge al P. Agustí Altisent, Tarragona, Diputació de Tarragona, 1991, pp. 73-93.

Marzal, Francisco Javier, La esclavitud en Valencia durante la Baja Edad Media (1375-1425), Valencia, Universitat de València, 2006. Tesis doctoral inédita. www.tdx.cat/bitstream/10803/9996/1/marzal.pdf [consulta: 21/09/2012].

Mazzi, María Serena, Prostitute e lenoni nella Firenze del Quattrocento, Milán, Il Saggiatore, 1991.

McVaugh, Michael R., Medicine before the plague. Practitioners and their patients in the Crown of Aragon, 1285-1345, Cambridge, Cambridge University Press, 1993.

Muñoz, Ángela; Segura, Cristina (eds.), El trabajo de las mujeres en la Edad Media hispana, Madrid, Al-Mudayna, 1988.

Narbona, Rafael, Gobierno político y luchas sociales. Estrategias de poder del patriciado urbano. La ciudad de Valencia (1356-1410), Valencia, Universitat de València, 1989, (tesis doctoral inédita). 
Narbona, Rafael, Tras los rastros de la cultura popular. Hechicerías, supersticiones y curanderismo en la Valencia medieval, "Edad Media. Revista de Historia" 1 (1998), pp. 91-110.

Oggins, Robin S., The Kings and their hawks. Falconry in Medieval England, New Haven - Londres, Yale University Press, 2004.

Ordenances municipals de Vila-real (segles XIV-XVIII), ed. a cargo de Vicent Gil, Valencia, Publicaciones de la Universitat de València, 2002.

Peyer, Hans Conrad, Viaggiare nel medioevo. Dall'ospitalità alla locanda, Roma - Bari, Laterza, 1990.

Park, Katharine, Medicine and society in medieval Europe, 500-1500, en Wear, Andrew (ed.), Medicine in society. Historical Essays, Cambridge, Cambridge University Press, 1992.

Picherit, Jean Louis, L'hôtellerie, les hôteliers et hôtelières dans quelques auvres de la fin du Moyen Âge, "Le Moyen Âge: Revue d'Histoire et de Philologie" 108 (2002), pp. 301-332.

Roca, Josep M., La medicina catalana en temps del rey Martí, Barcelona, Fidel Giró, 1919.

Rodrigo Pertegás, José, Historia de la antigua y real Cofradía de Nuestra Señora de los Inocentes Mártires y Desamparados de la venerada imagen y de su capilla, Valencia, Imprenta Hijos de F. Vives Mora, 1922.

Roig, Jaume, Espill, ed. a cargo de Antònia Carré, Barcelona, Quaderns Crema, 2006.

Rossiaud, Jacques, La prostitución en el Medievo, Barcelona, Ariel, 1986.

Rubio Vela, Agustín, Pobreza, enfermedad y asistencia hospitalaria en la Valencia del siglo XIV, Valencia, Alfons el Magnànim, 1984.

Rubio Vela, Agustín, El procés de Sueca. La mala vida en una comunitat rural del Trescents, Sueca, Bromera, 1988.

Rubio Vela, Agustín; Rodrigo, Mateu, Antroponímia valenciana del segle XIV, València, Institut Interuniversitari de Filologia Valenciana - Barcelona, Publicacions de l'Abadia de Montserrat, 1997.

Siraisi, Nancy, Medieval \& Early Renaissance Medicine, Chicago - Londres, The Chicago University Press, 1990.

Sermonario de San Vicente Ferrer, estudio y transcripción de Francisco Gimeno Blay, $\mathbf{M}^{\mathrm{a}}$ Luz Mandingorra Llavata, traducción de Francisco Calero, vol. I, Valencia, Ayuntamiento de Valencia, 2002.

Temkin, Owsei, Galenism. Rise and decline of a medical philosophy, Ithaca Londres, Cornel University, 1973.

Vela Aulesa, Carles, L'obrador d'un apotecari medieval segons el llibre de comptes de Francesc Ses Canes (Barcelona, 1378-1381), Barcelona, CSIC, 2003. 
Ventura i Conejero, Agustí, El castell de Xàtiva, Xàtiva, Matéu Impresores, 1998.

Viajes y viajeros en la España Medieval [Actas del V Curso de Cultura Medieval celebrado en Aguilar de Campoo (Palencia) del 20 al 23 de Septiembre de 1993], Madrid, Polifemo - Aguilar de Campoo, Fundación Sta. María la Real, 1997.

Vinyoles, Teresa, Història de les dones a la Catalunya medieval, Lleida, Pagès editors - Vic, Eumo Editorial, 2005.

Ysern i Lagarda, Josep-Antoni, Sant Vicent Ferrer: Predicació i societat, "Revista de Filologia Romànica” 20 (2003), pp. 73-102.

Fecha de recepción del artículo: noviembre 2012

Fecha de aceptación y versión final: mayo 2013 